\title{
Bitlis İlinin Doğal Afet Çeşitliliğinin Değerlendirilmesi
}

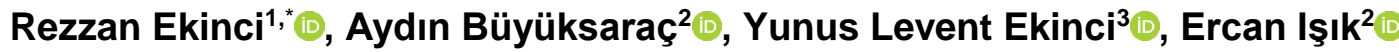

${ }^{1}$ Bitlis Eren Üniversitesi, Fen Bilimleri Enstitüsü, Acil Durum ve Afet Yönetimi Anabilim Dalı, Bitlis. ${ }^{2}$ Bitlis Eren Üniversitesi, Mühendislik Fakültesi, Inşaat Mühendisliği Bölümü, Bitlis.

${ }^{3}$ Bitlis Eren Üniversitesi, Fen Edebiyat Fakültesi, Arkeoloji Bölümü, Bitlis.

\section{Özet}

Bitlis ili hem jeomorfolojik yapısından hem de iklimsel özelliklerinden dolayı doğal afet türlerinin sıklıkla yaşandığ bir coğrafyada bulunmaktadır. Ancak, bu coğrafyada günümüze kadar gerekli düzeyde afet çeşitliliği envanteri çalışmaları ve buna bağlı olarak risk olasıllı̆̆ analizleri gerçekleştirilmemiştir. Bu çalışmada bir ilk olarak Bitlis ili sinırlarl içinde meydana gelmiş heyelan, çı̆̆ düşmesi, kaya düşmesi ve sel gibi çeşitli doğal afetlerin zamansal ve mekânsal analizi yapılmıştır. Doğal afetlerin meydana gelmesiyle oluşan zararlar da göz önüne alınarak risk değerleri hesaplanmış ve buna bağlı olarak risk sınıflandırması yapılmıştır. Risk analizleri yapabilmek amacıyla olasılık, şiddet ve frekans parametrelerinin kullanıldiğı yöntemlerden biri olan Fine-Kinney yönteminden

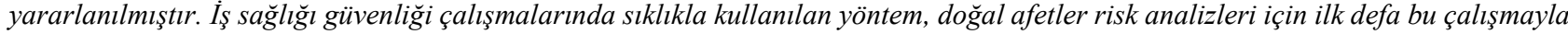
uygulanmış ve bu nedenle çalışmanın amacına uygun olabilecek yeni bir ölçek oluşturmuş ve hesaplamalar yapılmıştır. Heyelan, kaya düşmesi ve çığ olaylarının eğimli topografyalara sahip aynı zamanda da bol yağış alan yerleşim alanlarında günlük hayatı tehdit edecek seviyede olduğu belirlenmiştir. Ülkemizde çı̆̆ düşmesi olayından zarar görebilmeye en meyilli il olan Bitlis için olası bir afet anında uygulanabilecek acil durum eylemlerinin gerçekleştirilmesi önerilmektedir. Ayrıca, kaya düşmesi olaylarının yaşanma riskinin yüksek olduğu güney ilçelerde can ve mal kaybını önlemek amacıyla gerekli tedbirlerin acilen alınması gerekmektedir. Diğer taraftan, sel olayların ise ciddi bir tehlike arz etmediği belirlenmiștir.

\section{Anahtar Sözcükler}

Bitlis, Doğal Afet, Risk Analizi, Fine-Kinney Yöntemi

\section{Natural Disaster Diversity Assessment of Bitlis Province}

\begin{abstract}
Bitlis province is located on a geography where natural disasters occur frequently due both to their geomorphologic structure and climatic features. However, necessary studies for disaster diversity inventory and consequently risk probability analyses have not been performed so far. In this study, temporal and spatial analyses of various natural disasters such as landslides, avalanches, rockfalls and floods occurred in Bitlis province were performed. Considering the damages resulted from the natural disaster occurrences, risk scores were calculated for the classifications. In order to perform risk analyses, the Fine-Kinney method, which is a method that uses the parameters of probability, severity and frequency, was employed. In this study, the method which is frequently used in occupational health safety studies was applied to risk analyses of natural disasters for the first time and therefore a new scale compatible with the aim of the study was determined and computations were made accordingly. It was decided that landslide, rockfall and avalanche events threaten the daily life in the districts which have sloped topographies and generally get heavy rainfall. Emergency actions that can be applied in case of a possible avalanche disaster are strongly recommended for Bitlis province that is most prone to be damaged by avalanche events. In addition, necessary precautions should be taken immediately to prevent the loss of life and property in the south districts, where the risk of rockfall events is high. On the other hand, it was determined that flooding events do not pose a serious danger.
\end{abstract}

$\underline{\text { Keywords }}$

Bitlis, Natural Disaster, Risk Analysis, Fine-Kinney Method

\section{Giriş}

Tarih boyunca insanoğlunun karşılaştı̆ğ en büyük sorunlardan biri de hiç kuşkusuz ki doğal afetler olmuştur. Afetlerin Epidemiyolojisini Araştırma Merkezi (Centre for Research on the Epidemiology of Disasters, CRED) afet tanımı için; yerel imkanları yetersiz bırakan, küresel seviyede acil yardım gerektiren, önceden kestirilemeyen ve çoğunlukla birdenbire gelişen ve sonucunda büyük zararlara, yıkımlara ve insanların çeşitli acılar çekmesine sebep olan durum veya vaka ifadesini kullanmaktadır (Hoyois vd. 2007). Genel olarak afetler doğal kaynaklı olarak ve insan ihmalleri neticesinde oluşmaları bakımından iki başlık altında toplanmaktadır. İnsan yaşamını oldukça olumsuz yönde etkileyen doğal afetlerin en genel özelliği aniden gerçekleşebilmeleridir. 
Bu nedenle gerekli önlemlerin alınmamış olması durumunda oldukça ciddi can ve mal kayıpları yaşanabilir. Çoğunlukla jeolojik, topoğrafik, klimatolojik, meteorolojik ve biyolojik kökenli nedenlerin birinden veya birkaçından dolayı oluşan deprem, sel, fırtına, hortum, tayfun, yıldırım düşmesi, tsunami, heyelan, kaya düşmesi, çı̆̆ yeraltı suyu yükselmesi, kuraklık, yanardağ püskürmesi, meteor düşmesi, kıtlık, şiddetli soğuk veya sıcak hava koşulları, asit yağmurları, böcek istilaları vb. oldukça ciddi doğal afetlerin oluşabilmesine olanak sağlayabilmektedir. Diğer taraftan terör saldırıları, savaşlar, nükleer sızıntılar, biyolojik silahlar, çevre ve hava kirliliği, çevresel dengenin bozulması, su ve gıda kaynaklarının aşırı tüketilmesi gibi insan kaynaklı oluşan bu etmenler de oldukça ciddi afetlere neden olabilmektedir. Kökeni ne olursa olsun yukarıda sözü geçen afetler toplum yapısında bir bozulmaya neden olur, can ve mal kayıplarının yanında ciddi ekonomik ve sosyal kayıplara da yol açar (Uluğ 2009). Bu nedenle, afetler toplumun örgütlü biçimde hazırlıklı olması gereken en önemli sosyal ve çevresel sorunlar arasında yer almaktadır (Güler ve Çobanoğlu 1994). CRED tanımlamalarına göre afetler doğal ve teknolojik olarak gruplandırılmıştır. Buna göre, doğal afetler; hidro meteorolojik ve yersel olmak üzere iki üst başlıkta toplanmaktadır. Çı̆̆g, heyelan, kuraklık, kıtlık, uç değerlerdeki sıcaklık değerleri, sel, orman ve çalılık yangınları, kasırga, böcek istilaları ve deniz kabarmaları hidro meteorolojik kökenli afetler olarak tanımlanırken; deprem, tsunami ve volkanik patlamalar da yersel afetler olarak gruplandırılmıştır (Hoyois vd. 2007). Teknolojik afetler ise, endüstriyel kazalar (kimyasal sızıntılar, endüstriyel altyapı çökmeleri, yangınlar, gaz sızıntıları, zehirlenme ve radyasyona maruz kalma), ulaşım kazaları (hava, kara ve suyoluyla ulaşım kazaları) ve muhtelif kazalar (evsel veya endüstriyel olmayan yapıların çökmesi veya yıkılması, patlamalar ve yangınlar) olmak üzere üç üst başlıkta toplanmaktadır (Hoyois vd. 2007).

Bazı doğal afet çeşitleri sadece belirli coğrafyalarda değil küresel ölçekte de tüm dünyayı ve dolayısıyla tüm insanlığı tehdit edebilmektedir. Günümüze kadar, dünya genelinde milyonlarca insan doğal afetler nedeniyle hayatını kaybetmiştir. Tarih boyunca doğal afetlerden en fazla zarar görmüş ülkelerin başında Çin gelmektedir. Ülkemiz de yersel, jeomorfolojik, meteorolojik ve klimatolojik özellikleriyle doğal afetlerin oldukça sık yaşandığı ülkeler arasında yer almaktadır. Yakın geçmişte ülkemiz oldukça ciddi doğal afetler yaşamıştır. Örneğin, ülkemizin doğu bölgelerinde meydana gelen çı̆̆ felaketleri, 1992 Erzincan depremi, 1995 Senirkent heyelanı ve Dinar depremi, 1995 İzmir su baskını, 1999 Marmara depremi ve 2011 Van depremi oldukça büyük maddi ve manevi yıkımlara yol açmıştır. Ülkemizde 2007 yılına kadar son 70 yılda yaklaşık 600 bin konut doğal afetler nedeniyle hasar görmüştür. Bu toplamın yaklaşık \%66's1 depremlerden, \%10'u heyelanlardan, \%7'si kaya düşmelerinden ve \%2'si ise meteorolojik olaylar ve çı̆̆ düşmelerinden kaynaklanmıştır (Özkul ve Karaman 2007). Yapılan bir araştırmaya göre 1970 ve 2012 yılları arasında ülkemizde belirli bir afet türünden en fazla etkilenen iller belirlenmiştir. Buna göre; Denizli, İzmir ve Bingöl'de 14-17 deprem olayı, Bingöl, Bitlis ve Erzurum'da 16-40 sel/su baskını olayı, Malatya, İzmir ve Nevşehir'de 14-29 don olayı ve Mersin, Antalya ve Nevşehir'de 24-29 dolu olayı, Hakkari, Bingöl ve Bitlis’te 18-31çı̆̆ olayı, Balıkesir, Nevşehir ve Elazı̆̆'da 38-64 firtına olayı, İzmir, Muğla ve Antalya'da 244-269 orman yangını olayı, Rize, Artvin ve Erzurum'da 53-58 heyelan olayı ve Artvin, Kayseri ve Erzurum'da 18-31 kaya düşmesi olayı, Ağrı, Trabzon ve Kocaeli'de 3-6 yıldırım düşmesi olayı, Antalya ve Bitlis'te 4-22 şiddetli yağış olayı, Şanlıurfa ve Nevşehir'de 5-7 kuraklık olayı ve son olarak İstanbul ve Rize'de ise 8-11 sis olayı meydana gelmiştir (Özşahin 2013).

Ülkemizdeki yerleşim yerlerinin neredeyse tümü en az bir doğal afete yatkın alanlar üzerinde kuruludur. T.C. Afet ve Acil Durum Başkanlığı (AFAD) tarafından yayınlanan 1950-2008 yılları arasında meydana gelmiş ve belli bir derecede afete neden olmuş heyelan, çı̆̆ kaya düşmesi ve sel (su basması) olaylarının sayıları ve bu afet olaylarının illere göre dağılımını gösteren haritalar (Gökçe 2008) yayınlanan verilere sadık kalınarak bu çalışma için yeniden üretilmiştir (Şekil 1). Bu haritalarda Bitlis ili işaretlenerek, Türkiye genelinde dört farklı afet türüne göre hangi konumda olduğu görsel olarak sunulmuştur. AFAD tarafindan yapılan araştırmalara göre, ülkemizde 1950-2008 yılları arasında meydana gelen doğal afetler, Gayri Safi Milli Hasılamızın \%3-4'ü oranında bir ekonomik kayba neden olmasını sağlamıştır (Gökçe vd. 2008). Ülkemizde sözü geçen yıllar arasında meydana gelmiş ve bu çalışmada değinilen doğal afet çeşitlerinden etkilenmiş yerleşim alanlarının sayıları ve oranları Tablo 1'de verilmiştir. Bu bilgilerden anlaşılacağı üzere ülkemizde doğal afet riski oldukça yüksektir. Bu nedenle doğal afetleri tanımak ve olası tehlikelere karşı hazırlıklı olup gerekli altyapı çalışmalarını tamamlamak, oluşabilecek maddi ve manevi olumsuzlukları azaltmada kilit bir rol oynayabilir.

Tablo 1:Ülkemizde 1950-2008 yılları arasında meydana gelmiş bazı afet türleri ve bu afetlerden etkilenmiş yerleşim yeri sayıları ve oranları (Gökçe vd. 2008)

\begin{tabular}{ccc}
\hline Afetler & $\begin{array}{c}\text { Afet Gören Yerleşim } \\
\text { Birimi Sayısı }\end{array}$ & $\begin{array}{c}\text { Toplam Yerleşim Birimi } \\
\text { Sayısına Oranı (\%) }\end{array}$ \\
\hline Heyelan & 5472 & 15.31 \\
Kaya Düşmesi & 1703 & 4.76 \\
Çığ & 605 & 1.69 \\
Sel & 2924 & 8.18 \\
\hline
\end{tabular}

Bu çalışmaya konu olan Bitlis ili doğal afet çeşitlerinin birçoğunun sıklıkla görüldüğü bir coğrafyanın üzerinde kurulu olmasına karşın, doğal afet çeşitliliğinden ziyade sadece özel bir konuyu veya tek bir doğal afet çeşidini kapsayan çalışmalar yapılmıştır. Gerçekleştirilen bu çalışmalardan bazıları izleyen şekilde özetlenebilir: 


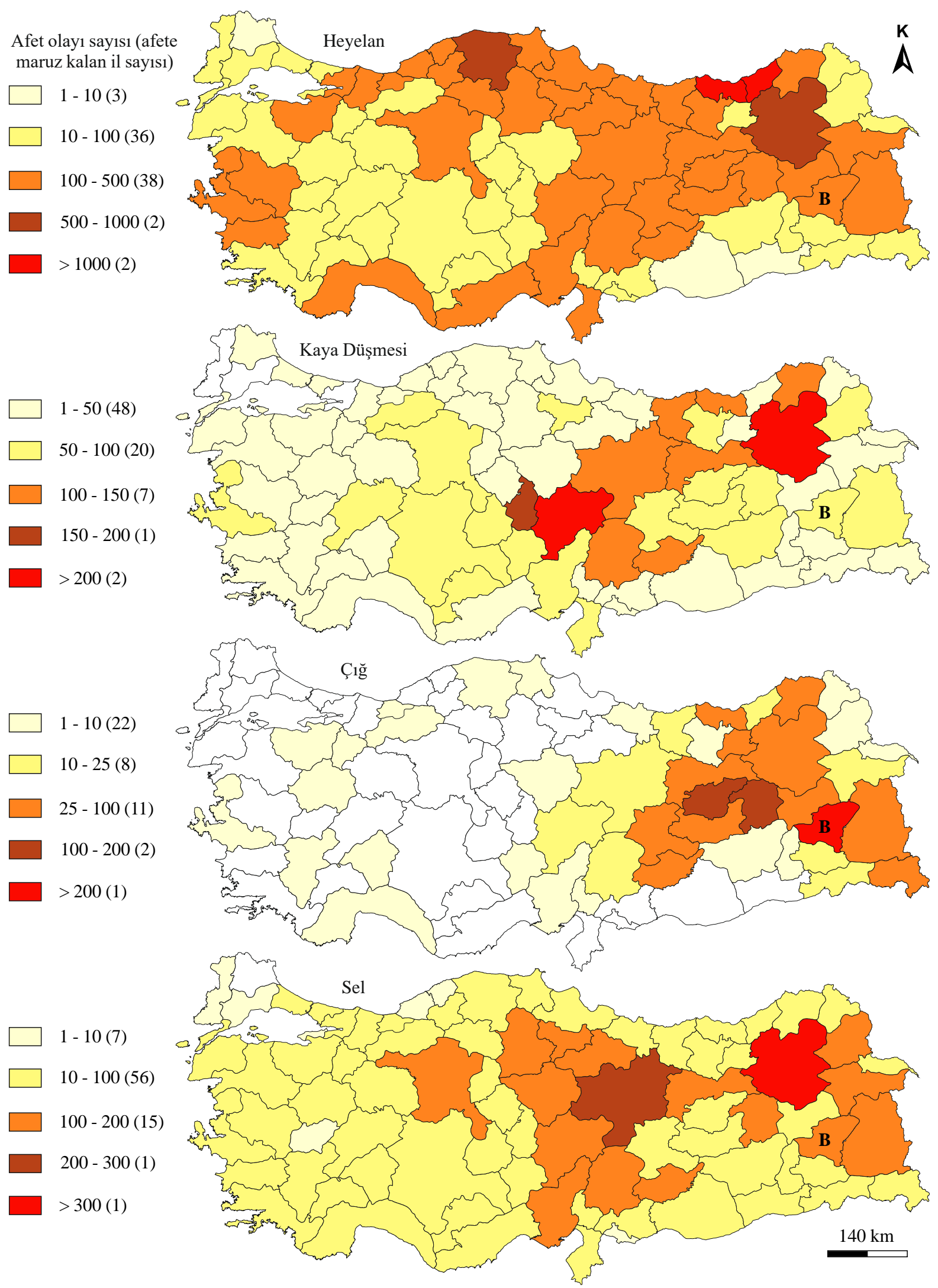

Şekil 1: Heyelan, kaya düşmesi, çığ ve sel olayları sayılarının illere göre dağıımı. Parantez içi rakamlar afetten etkilenen il sayılarını göstermektedir (Gökçe 2008'den yeniden çizilmiştir). B harfi Bitlis ilini ifade etmektedir 
Elmastaş ve Özcanlı (2011), Bitlis ilindeki çı̆̆ düşmesi potansiyeline sahip alanları belirlemişler ve çı̆̆ risk analizini kar kalınlığı ve eğim şartları göz önüne alınarak gerçekleştirmişlerdir. Bitlis ilinin eğim haritalarını hazırlamışlar ve ilde bulunan yerleşmelerin eğime bağlı olarak çı̆̆ afeti için hangi risk grubunda olduklarını belirlemişlerdir. Özşahin ve Kaymaz (2014), Doğu Anadolu'nun çığ duyarlığı ve riskini hesaplamışlardır. Buna göre çığ olayı gözlenen 29 şehir içerisinde Bitlis 31 adet olayla ilk sırada yer almıştır. Özdemir vd. (2017) Süphan Dağ1 çöküntülerinin Van Gölü’nde oluşturabileceği tsunami tehlikesi için farklı senaryolarla bazı modelleme çalışmaları gerçekleştirmişler ve riskli yerleşim yerlerini belirlemişlerdir. Işık vd. (2012), Van Gölü Havzasında bulunan Bitlis ili ve yakın çevresinde tektonik hareket oluşturabilecek fayların özelliklerini incelemişlerdir. Bitlis il merkezinin etrafinda bir bölge (150 km yarıçaplı dairesel bölge) kullanılarak yapılan çalışmada Bitlis ve yakın çevresinin sismik açıdan çok aktif olduğu sonucuna varılmıştır. Bu yüzden gelecekte oluşabilecek depremler için sismo tektonik çalışmaların yapılmasının, yapılaşma sırasında da bu sonuçların göz önünde bulundurularak dayanıklı yapı tasarımının gerekliliğini belirtmişlerdir. Bulut vd. (2018) Bitlis il merkezinde yaptıkları çalışmada kent merkezi için önemli bir yaşamsal sorun haline gelmiş ve zaman zaman da hayatı etkilemesi nedeniyle afet kapsamına giren kaya düşmesi olaylarının acil önlem alınmasını gerektirecek boyutta olduğunu belirtmişlerdir. Ayrıca, kaya düşmesi potansiyeline sahip olan alanları belirlemişler ve düşmeye sebep olabilecek etkenleri ortaya koymuşlardır. Ekinci vd. (2018), Bitlis ili ve yakın çevresinin sismik riskini ele almışlar ve istatistiksel çalışmalar yapmışlardır. Böylece çalışma bölgesinde herhangi bir büyüklükteki depremin olma olasılıkları ve geri dönüş periyodları stokastik şekilde belirlenmiştir.

Yukarıda verilen çalışmalardan farklı olacak şekilde bu çalışmada Bitlis ili için heyelan, kaya düşmesi, çı̆̆ ve sel gibi doğal afet çeşitliliği incelenmiştir. Gerçekleşen doğal afet çeşitlerinin zamansal ve mekânsal dağılımları belirlenmiştir ve ayrıca geçmişte gerçekleşmiş doğal afet verileri yardımıyla afet risk analizleri yapılmıştır. Bu kapsamda, iş sağlığı ve güvenliği çalışmalarında oldukça sık bir şekilde uygulanan ve olasılık, şiddet ve frekans parametrelerinin kullanıldığı Fine-Kinney yöntemi bir ilk olarak doğal afet verileri için yeniden düzenlenmiş ve böylece Bitlis ili ve ilçeleri için afet türlerinin risk skorları belirlenmiştir.

\section{2. Çalışma Alanı}

Yukarı Fırat ve Yukarı Murat bölgeleri üzerinde yer alan Bitlis ilinin merkez ilçesiyle birlikte toplam 7 ilçesi (Adilcevaz, Ahlat, Güroymak, Hizan, Mutki ve Tatvan) bulunmaktadır (Şekil 2). Van Gölü’nün batısında bulunan Bitlis il merkezi deniz seviyesinden yaklaşık 1550 m yüksekliktedir ve ilin coğrafi sınırlarının yaklaşık \%71'i dağlık arazi, \%19'u plato ve \%10'u da ovalardan oluşmaktadır (Gür vd. 2012). Ahlat ve Rahva Ovalarından başka büyük düzlüklerin yer almadığı oldukça engebeli bir topoğrafyaya sahip Bitlis ilinin en yüksek alanları Adilcevaz ilçesi civarındadır.

Bitlis ili sınırları içinde yer alan Nemrut Volkanik Dağı merkeze yaklaşık 24 km uzaklıkta bulunmaktadır. Nemrut kraterinin zirve yüksekliği deniz seviyesinden yaklaşık 2950 m'dir (Şekil 3). Fiziksel gelişimini 3 ana evrede (kaldera öncesi, kaldera sonrası ve geç evre) tamamlayan (Y1lmaz vd. 1998, Karaoğlu vd. 2005, Çubukçu vd. 2012) ve uyuyan aktif bir yanardağ olarak tanımlanan (Ulusoy vd. 2012) Nemrut Dağı'nda 1 milyon yıl önce başlayan volkanik aktivite en son 1441, 1597 ve 1692 yıllarındaki patlamalarla devam etmiştir (Karakhanian 2002, Aydar vd. 2003, Ulusoy vd. 2008, Çubukçu vd. 2012). Bitlis’in Adilcevaz ilçesi sınırları içinde bir kısmı yer alan Süphan Dağı (Şekil 3), Büyük Ağrı Dağı'ndan sonra ülkemizdeki volkanik kökenli en yüksek (4058 m) dağdır (Deniz vd. 2006). Bu dağda meydana gelen son püskürmenin yaklaşık 10 bin yıl önce gerçekleştiği tahmin edilmektedir (Y1lmaz vd. 1998).

Volkanik bir alan üzerinde kurulu olan Bitlis ili, Tatvan ilçesinde bulunan perlit ve pomza yatakları bakımından önemli potansiyele sahiptir (MTA 2010). Güneydoğu Türkiye'de Toros Dağları'nda bulunan metamorfik ve magmatik kayalardan meydana gelmiş kütle Bitlis masifi olarak bilinmektedir (Boray 1975). Bitlis masifi çekirdek kayaçları (Yolcular Formasyonu) amfibolit, mikroklin gnays, biyotit gnays/şist ve muskovit gnays/şist ile bunları kesen biyotit granit ve hololökokratikgranitik fazdan oluşmaktadır (Şengün 1993). Bitlis masifinin çok evreli metamorfizmaya uğradığı görüşü genel olarak kabul edilmektedir (Boray 1973, Mason 1975, Hall 1976). Bitlis masifinin orta bölümü, her biri kendi içinde pek çok tektonik dilimi kapsayan 3 tektonostratigrafik birimden oluşmakta ve en üstte Bitlis metamorfik kuşağ1, altında dilimli kuşak ve en altta da otokton kuşak yer alırken, alt metamorfitler Bitlis metamorfik kuşağ içindeki Hizan metamorfitleri olarak adlandırılmaktadır (Göncüoğlu ve Turhan 1983).

Arap ve Avrasya plakalarının çarpışması ile oluşan tektonik basınç sonucu gelişen (McKenzie 1970, Öztürk vd. 2005) ve bir kısmı Bitlis ili sınırları içinde bulunan Van Gölü, Doğu Anadolu'da oldukça yoğun deformasyon geçirmiş bir tektonik yapı içinde bulunmaktadır (Işık 2013). Van Gölü, yaklaşık olarak $451 \mathrm{~m}$ derinliği ve de $607 \mathrm{~km}^{3}$ hacmiyle Hazar Gölü, Aral Gölü ve Issık (Issykkul) Gölü’nden sonra su içeriği bakımından kapalı göller arasında dünyada dördüncü büyük göl olma özelliğini taşır (Degens vd. 1984). Deprem aktivitesi Van Gölü çevresinde oldukça yüksek seviyededir (Horasan ve Boztepe-Güney 2007, Toker vd. 2007). Ayrıca, Van Gölü havzasında meydana gelebilecek büyük ve yıkıcı bir depremin Bitlis ilini ciddi bir şekilde etkileyebilme riski bulunmaktadır. Günümüze kadar büyüklüğü 5.0 ve 6.0 arasında değişen bazı depremler Bitlis iline oldukça yakın bir konumda gerçekleşmiştir. Ayrıca, Bitlis iline yakın sayılabilecek Kuzey Anadolu Fay Zonu ve Doğu Anadolu Fay Zonu boyunca ve Van Gölü’nün özellikle doğu kısmında deprem aktivitesi oldukça fazladır. Buna karşın Bitlis-Zagros Kenet Kuşağı'nın güney kısmı için deprem yoğunluğunda gözle görülür bir azalım söz konusudur. 


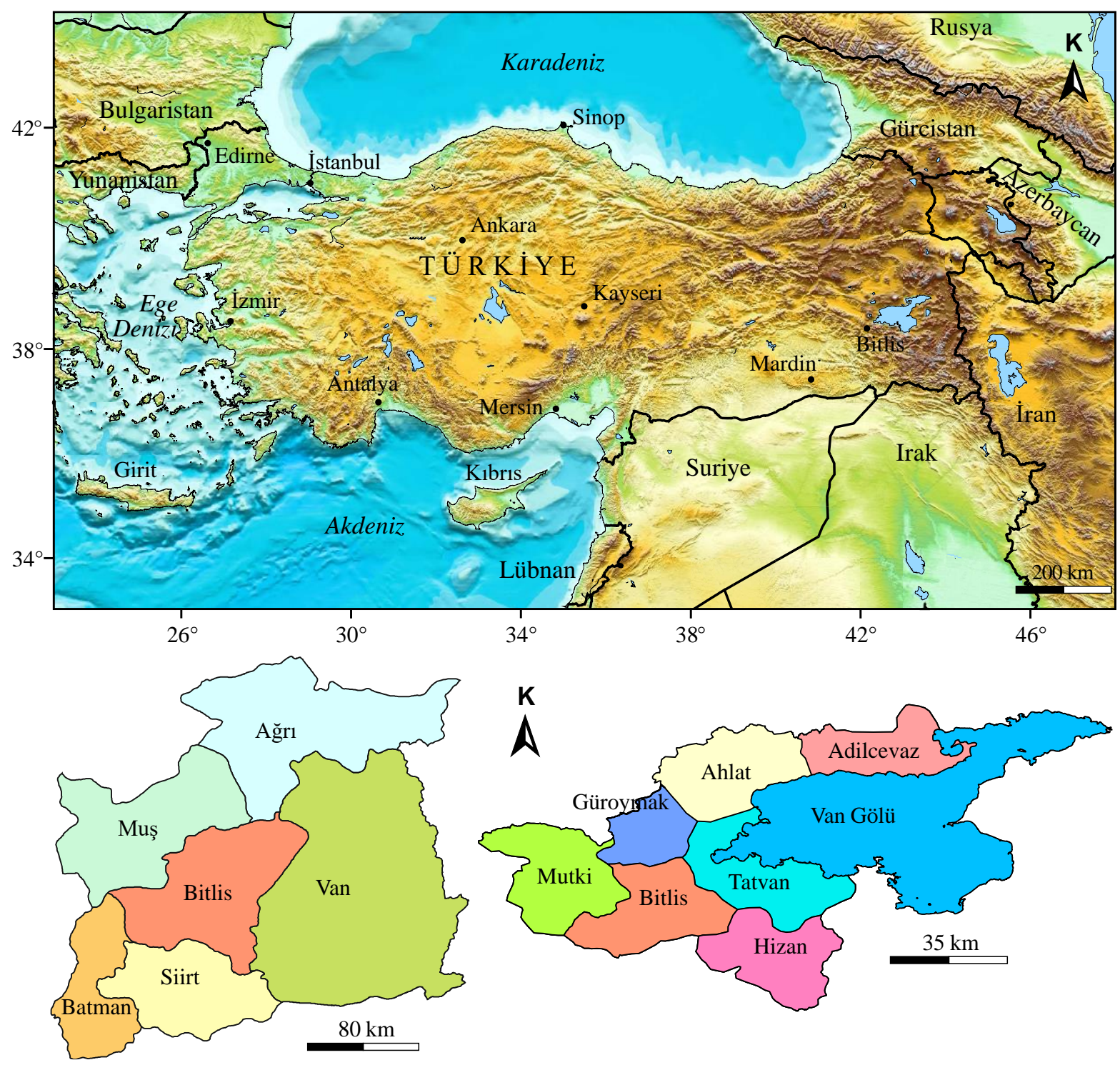

Şekil 2: Bitlis ili ve ilçelerini gösteren haritalar. Topoğrafik harita GMT (Wessel ve Smith 1995) yazılımı ile üretilmiştir

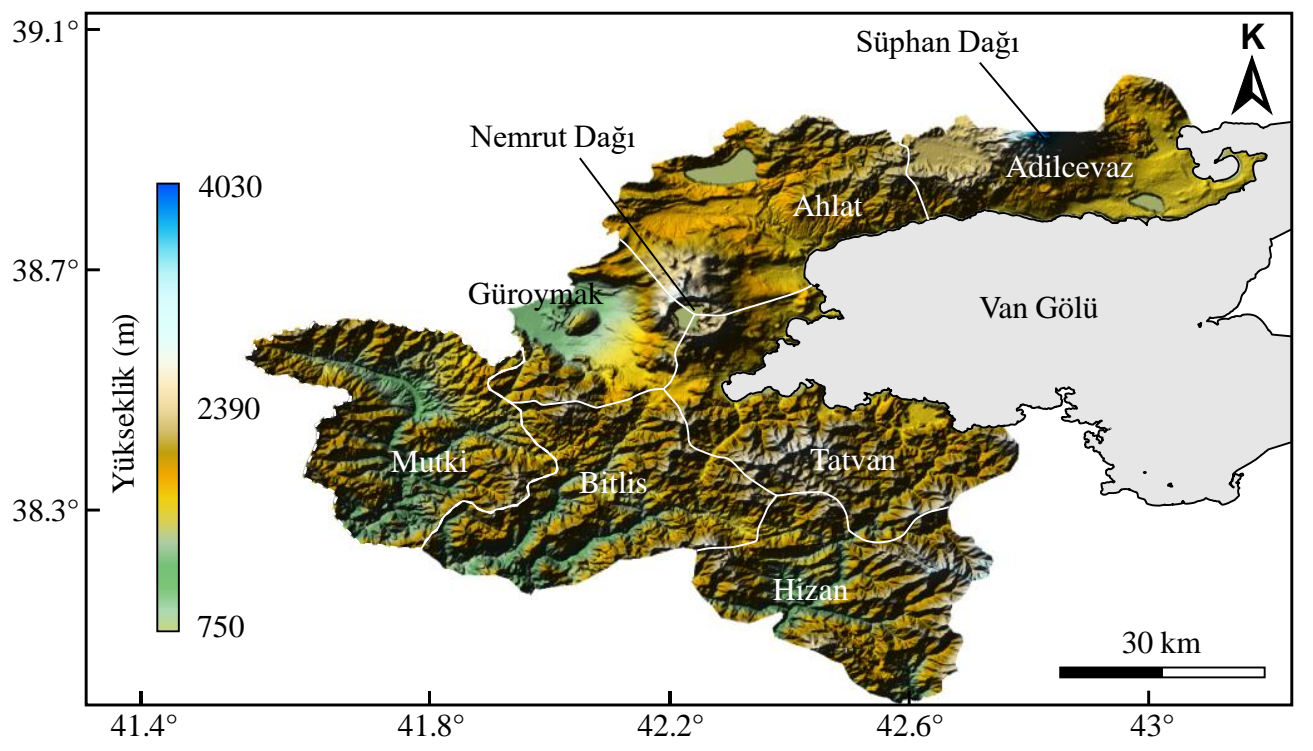

Şekil 3: Bitlis ilinin sayısal yükseklik modeli 


\section{Fine-Kinney Yöntemi}

İş sağlığı güvenliği alanında risk analizi hesaplamaları yapmak için uygulanan Fine-Kinney yöntemi ilk olarak Fine (1971) tarafından önerilmiş ve sonraları Kinney ve Wiruth (1976) tarafından daha detaylı bir risk analizi yöntemi haline getirilmiştir. Günümüze kadar bu yöntemle gerçekleştirilmiş ve yayınlanmış birçok çalışma bulunmaktadır. Özçelik (2013) tarafından gerçekleştirilen çalışmada bir işletmedeki tehlikelerin oluşturabileceği riskler belirlenmiştir. Belirlenen riskler Fine-Kinney yöntemi kullanılarak analiz edilmiş ve bu risklerin gerçekleşmemesi için alınacak önlemler belirtilmiştir. Önlemler alındıktan sonra kalan riskler tekrar belirlenmiş ve risk yönetim sistemi aracılığıyla işletmede çalışma koşulları iyileştirmeye çalışılmıştır. Oturakçı vd. (2015) Fine-Kinney yöntemindeki ihtimal ve frekans ölçeklerine farklı alternatif ölçekler oluşturmuşlar, daha yüksek ihtimale ve daha sık frekansa sahip tehlikelerin ölçekteki puanlarını yükselterek hassasiyet ve önem derecelerini daha da arttırmışlardır. Geliştirdikleri yeni ölçeklerle güneş panelleri üretimi ve dağıtımını yapan orta ölçekli bir işletmedeki risk analizini gerçekleştirmişlerdir. Okumuş ve Barlas (2015) gemi inşaatı sektöründeki kazalar için 5×5 analiz matrisi ve Fine-Kinney yöntemleriyle risk analizi çalışmaları yapmışlar ve bu iki yöntemin karşılaştırmaları üzerinde durmuşlardır. Hosny vd. (2017) Mısır'da petrol rafinelerinin bulunduğu üç farklı alanda farklı seviyede benzine maruz kalmış işçilerin sağlık durumları için Fine-Kinney yöntemi kullanarak risk analizi yapmışlardır. İki alanda kanser risk dereceleri yüksek bulunurken, diğer alanda ise modern mühendislik ve güvenlik önlemlerinden dolayı bu oranın daha düşük olduğu tespit edilmiştir. Birgören (2017) yöntemin parametrelerinin ve kısıtlarının endüstriyel uygulamacılar için daha iyi anlaşılabilmesi amacıyla bazı problemler ortaya koyarak çözümleri üzerinde durmuştur. Bu yöntemde risk değerinin (R) hesaplanabilmesi için Eşitlik (1) kullanılır. Burada F; frekansı, O; olasılığg ve D; şiddet değerini ifade etmektedir.

$$
\mathrm{R}=\mathrm{F} \times \mathrm{O} \times \mathrm{D}
$$

Fine-Kinney yönteminde risk değerinin doğru hesaplanabilmesi için kullanılan parametre değerlerinin iyi anlaşılması ve doğru değer tahmininin yapılması gerekir. Bu doğrultuda Eşitlik (1) de kullanılacak değerlerin ifade ettiği kategori bilgileri frekans için Tablo 2'de, olasılık için Tablo 3'te ve şiddet için Tablo 4'te verilmiştir. Üç değişkene göre ulaşılan risk değeri ise Tablo 5 'te verilen dağılıma göre sınıflandırılmaktadır.

Tablo 2: Kinney ve Wiruth (1976) tarafından belirlenmiş frekans ölçeği

\begin{tabular}{ccc}
\hline Değer & Açıklama & Kategori \\
\hline 0.5 & Çok Nadir & Yilda bir ya da daha az \\
1 & Nadir & Y1lda bir ya da birkaç kez \\
2 & Seyrek & Ayda bir ya da birkaç kez \\
3 & Ara sira & Haftada bir ya da birkaç kez \\
6 & Sıklıkla & Günde bir ya da daha fazla \\
10 & Sürekli & Sürekli ya da saatte birden fazla \\
\hline
\end{tabular}

Tablo 3: Kinney ve Wiruth (1976) tarafından belirlenmiş olasılık ölçeği

\begin{tabular}{cc}
\hline Değer & Kategori \\
\hline 0.2 & Pratik olarak imkânsız \\
0.5 & Zayıf ihtimal \\
1 & Oldukça düşük ihtimal \\
3 & Nadir fakat olabilir \\
6 & Kuvvetle muhtemel \\
10 & Çok kuvvetli ihtimal \\
\hline
\end{tabular}

Tablo 4: Kinney ve Wiruth (1976) tarafından belirlenmiş şiddet ölçeği

\begin{tabular}{ccc}
\hline Değer & Açıklama & Kategori \\
\hline 1 & Dikkate alınmalı & Hafif-zararsız veya önemsiz \\
3 & Önemli & Düşük iş kaybı, küçük hasar, ilk yardım \\
7 & Ciddi & Önemli zarar, dış tedavi, iş günü kaybı \\
15 & Çok ciddi & Sakatlık, uzuv kaybı, çevre etkisi \\
40 & Çok kötü & Ölüm, tam maluliyet, ağır çevre etkisi \\
100 & Felaket & Birden çok ölüm, önemli çevre felaketi \\
\hline
\end{tabular}


Tablo 5: Kinney ve Wiruth (1976) tarafından belirlenmiş risk değeri sınıflandırılması

\begin{tabular}{ccc}
\hline Risk Değeri & Karar & Eylem \\
\hline $\mathrm{R}<20$ & Kabul Edilebilir Risk & Acil tedbir gerekmeyebilir \\
$20<\mathrm{R}<70$ & Kesin Risk & Eylem planına alınmalı \\
$70<\mathrm{R}<200$ & Önemli Risk & Dikkatle izlenmeli, y1llik eylem planı \\
$200<\mathrm{R}<400$ & Yüksek Risk & Kisa vadeli eylem planı \\
$\mathrm{R}>400$ & Çok Yüksek Risk & Derhal tedbir \\
\hline
\end{tabular}

Bitlis il merkezi ve ilçeleri için 1965-2010 yılları arasında gerçekleşmiş heyelan, çı̆̆ düşmesi, kaya düşmesi ve sel verileri incelenerek risk değerlerinin elde edilebilmesi amacıyla Fine-Kinney yöntemindeki frekans ve şiddet ölçekleri doğal afetler için yeniden uyarlanmıştır. Şöyle ki Tablo 2'de görüleceği üzere herhangi bir işletmede herhangi bir kazanın veya olumsuz bir olayın yılda bir gerçekleşiyor olması durumunda, o olayın tekrarlanma sıklığı için "çok nadir" ifadesi kullanılmaktadır. Ancak bu kategori ve açıklamanın bir doğal afet olayı için kullanılması uygun değildir. Örneğin belirli bir yerleşim alanında ortalama yılda bir gerçekleşen heyelan olayı onun çok nadir değil de sıklıkla meydana gelen bir doğal afet olduğu anlamına gelmektedir. Yine aynı şekilde herhangi bir ilçe sınırları içinde haftada bir veya birkaç kez meydana gelen kaya düşmesi veya sel olayları için ara sıra oluşuyor ifadesinin kullanılamayacağı oldukça açıktır. Bu nedenle yöntemde kullanılan ve yukarıda verilen ölçeklerin ve kategorilerin doğal afetler için yeniden düzenlenmesi gerekmiştir. Buna göre heyelan, kaya düşmesi, çı̆̆ ve sel gibi doğal afetlerin oluşumları, olası tekrarlanma süreleri ve oluşturabileceği sonuçlar göz önüne alınarak frekans ve şiddet ölçekleri makul olabilecek şekilde güncellenmiş ve sırasıyla Tablo 6 ve 7'de verilmiştir. Bunların dışında kalan olasılık ölçeğinin ise Tablo 3'teki aslına uygun şekilde kullanılmasının yeterli olacağı öngörülmüştür.

Tablo 6: Fine-Kinney yönteminde kullanılmak için yeniden düzenlenmiş frekans ölçeği

\begin{tabular}{ccc}
\hline Değer & Açıklama & Kategori \\
\hline 0.5 & Çok Nadir & Elli yılda bir \\
1 & Nadir & On yılda bir \\
2 & Seyrek & Beş yılda bir \\
3 & Ara sira & İki yılda bir \\
6 & Siklıkla & Y1lda bir \\
10 & Sürekli & Yılda birden fazla \\
\hline
\end{tabular}

Tablo 7: Fine-Kinney yönteminde kullanılmak için yeniden düzenlenmiş şiddet ölçeği

\begin{tabular}{ccc}
\hline Değer & Açıklama & Kategori \\
\hline 1 & Dikkate alınmalı & Etkilenen konut bulunmaması \\
3 & Önemli & Kontrol etüt programı \\
7 & Ciddi & Bina hafif hasarlı \\
15 & Çok ciddi & Bina ağır hasarlı \\
40 & Çok kötü & Yaralanma \\
100 & Felaket & Ölüm, ağır yaralı \\
\hline
\end{tabular}

\section{Bulgular}

Bitlis il merkezi ve ilçeleri için heyelan, çı̆̆g, kaya düşmesi ve sel gibi doğal afet olaylarının zamansal ve mekânsal dağılımları incelenmiş ve risk analizi çalışmaları yapılmıştır. Bu amaçla, öncelikle resmi kayıtlara ait geçmiş doğal afet olaylarının mekânsal dağılımlarını göstermek üzere sayısal ortamda haritalar üretilmiştir. Ayrıca, zamansal dağılımları göstermek için beşer yıllık zaman aralıklarına göre oluş sayılarını gösteren grafikler oluşturulmuştur.

Şekil 4’te 1965-2010 yılları arasında gerçekleşmiş heyelan olaylarının mekânsal dağılımını gösteren harita incelendiğinde, en fazla heyelan olayının Hizan ilçesinde gerçekleştiği, ayrıca Bitlis il merkezi sınırları içinde ve Mutki ilçelerinde de oldukça fazla sayıda heyelan olayının meydana geldiği görülmektedir. Ayrıca Güroymak ve Tatvan ilçelerinde de eğimli topografyanın gözlemlendiği bölgelerde heyelan olaylarının meydana geldiği görülmektedir. Eğimli topografyanın daha az olduğu Ahlat ve Adilcevaz ilçelerinde ise beklenildiği gibi heyelan olayı sayısı oldukça azdır. Bitlis il merkezi ve ilçelerinde toplam 58 olayla en fazla heyelanın gözlendiği yıllar 2005-2010 yılları arasıdır (Şekil 5). Bu yıllarda heyelan olaylarının artışının iklimsel koşullardan kaynaklandığı düşünülmektedir. 1985 yılından önceki değerlerin diğer yıllara göre daha az olmasının nedeninin ise sözü geçen yıllardaki olanaksızlıklardan dolayı eksik veri kayıt edilmesi olduğu düşünülmektedir. 
Şekil 4'de verilen Bitlis ilinde meydana gelmiş çı̆̆ olayı yerlerini gösteren harita incelendiğinde, eğimli topografyanın fazla olduğu ve kar yağışlarının yoğun olarak gözlendiği Mutki, Hizan, Tatvan ve Merkez ilçelerinde kayıt edilmiş birçok çı̆̆ olayının yaşandığı görülmektedir. Ahlat ilçesinde ise hiç çı̆̆ olayı gerçekleşmezken Adilcevaz ilçesinde ise sadece bir lokasyonda çı̆̆ olayı meydana gelmiştir. 1990-1995 ve 2005-2010 yılları arasında çı̆̆ olaylarının oluş sayısında önemli bir artış olduğu görülmektedir (Şekil 5). Bu artışın o yıllardaki yoğun kar yağışı ve uzun kış koşullarından kaynaklandığı düşünülmektedir. 1965-1975 yılları arasındaki çı̆̆ olayı sayısının az olması kayıt eksikliğinden kaynaklanabilir.

Türkiye'de kaya düşmesi olaylarının ortalamanın üzerinde yaşandığı illerden biri olan Bitlis ilinde Mutki, Hizan ve Merkez ilçelerinde kaya düşmesi olayı oldukça fazla gözlenmiştir (Şekil 4). Ahlat, Adilcevaz ilçelerinde birer lokasyonda meydana gelen kaya düşmesi olayı Tatvan ilçesinde daha fazla gözlenmektedir. 1965-2010 yılları arasında Güroymak ilçesinde hiçbir kaya düşmesi olayı kaydı yoktur. Kaya düşmesi olayları en çok 1985-1990 ve 2005-2010 yılları aralığında meydana gelmiştir (Şekil 5).

Sel olayı verilerine bakıldığında Mutki ilçesinde diğer ilçelere göre daha fazla sel olayının gerçekleştiği görülmektedir (Şekil 4). Tatvan ve Adilcevaz ilçelerinde sel olayı sayısı azalım gösterirken Merkez ilçe, Güroymak ve Hizan ilçelerinde ise sel olaylarının daha fazla yaşandığı görülmektedir (Şekil 4). Ahlat ilçesinde ise sadece iki lokasyonda sel olayı gözlenmiştir. Sadece 1970-1975 yılları arasında gözlenmeyen sel olaylarının 2005-2010 yılları arasındaki fazlalığının (Şekil 5) nedenin ise o yıllardaki aşırı kar ve sağanak yağışlardan, yerde kalan kar süresinin uzunluğundan ve sonucunda da ani eriyen kar sularından kaynaklandığı düşünülmektedir.

Fine-Kinney yöntemiyle hazırlanan heyelan risk analizi sonuçlarına bakıldığında Hizan ve Mutki ilçelerinin çok yüksek risk değerlerine sahip olduğu görülmektedir (Tablo 8). Ahlat, Güroymak ve Tatvan ilçelerinde kesin risk sonucu hesaplanırken, Adilcevaz ilçesinde kabul edilebilir risk sonucu elde edilmiştir. Çı̆̆ risk analizi sonuçlarına göre Merkez, Mutki ve Tatvan ilçelerinde çok yüksek risk değeri sonuçları elde edildiği görülmektedir (Tablo 8). Hizan ilçesinde yüksek risk değeri, Güroymak ve Adilcevaz ilçelerinde ise kabul edilebilir risk değeri bulunmuştur. Ahlat ilçesinde ise herhangi bir çı̆̆ olayı riski bulunmamaktadır. Kaya düşmesi olayı için risk değerlerinin ise Merkez, Mutki ve Hizan ilçelerinde yüksek olduğu (Tablo 8), Adilcevaz, Ahlat ve Tatvan ilçelerinde ise kabul edilebilir risk değerleri olduğu görülmektedir. Güroymak ilçesinde ise afete neden olan herhangi bir kaya düşmesi olayı gerçekleşmediğinden risk değeri hesaplanmamıştır. Sel risk analizi değerlerinde (Tablo 8) ise yüksek risk değeri Mutki ilçesi için hesaplanmıştır. Güroymak, Hizan ve Merkez ilçelerinde kesin risk değeri, Adilcevaz, Ahlat, Tatvan ilçelerinde ise kabul edilebilir risk değeri elde edilmiştir.
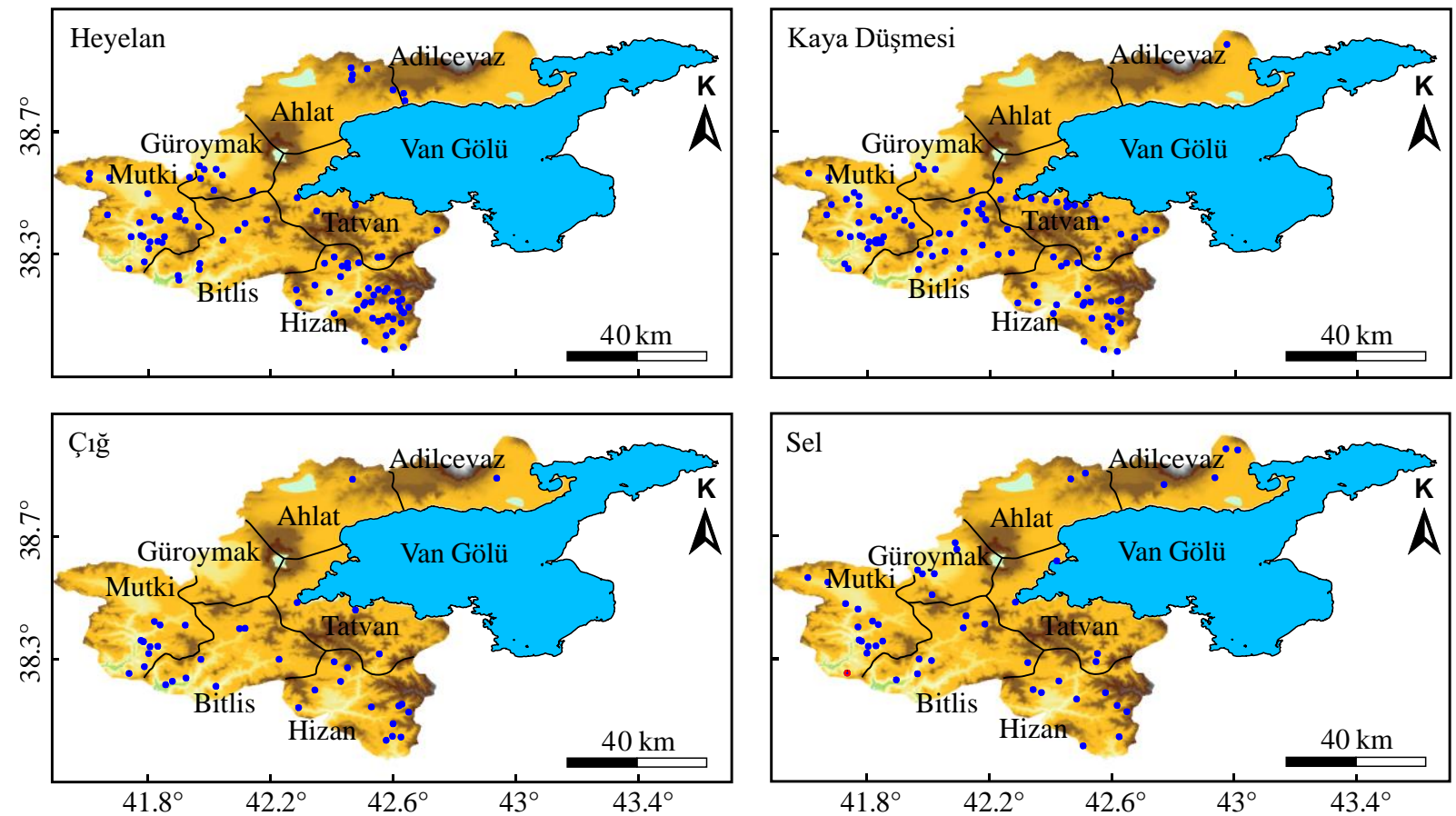

Şekil 4: Bitlis ilinde 1965-2010 yılları arasında gerçekleşmiş heyelan, çı̆̆, kaya düşmesi ve sel olaylarının oluş yerlerini gösteren haritalar 

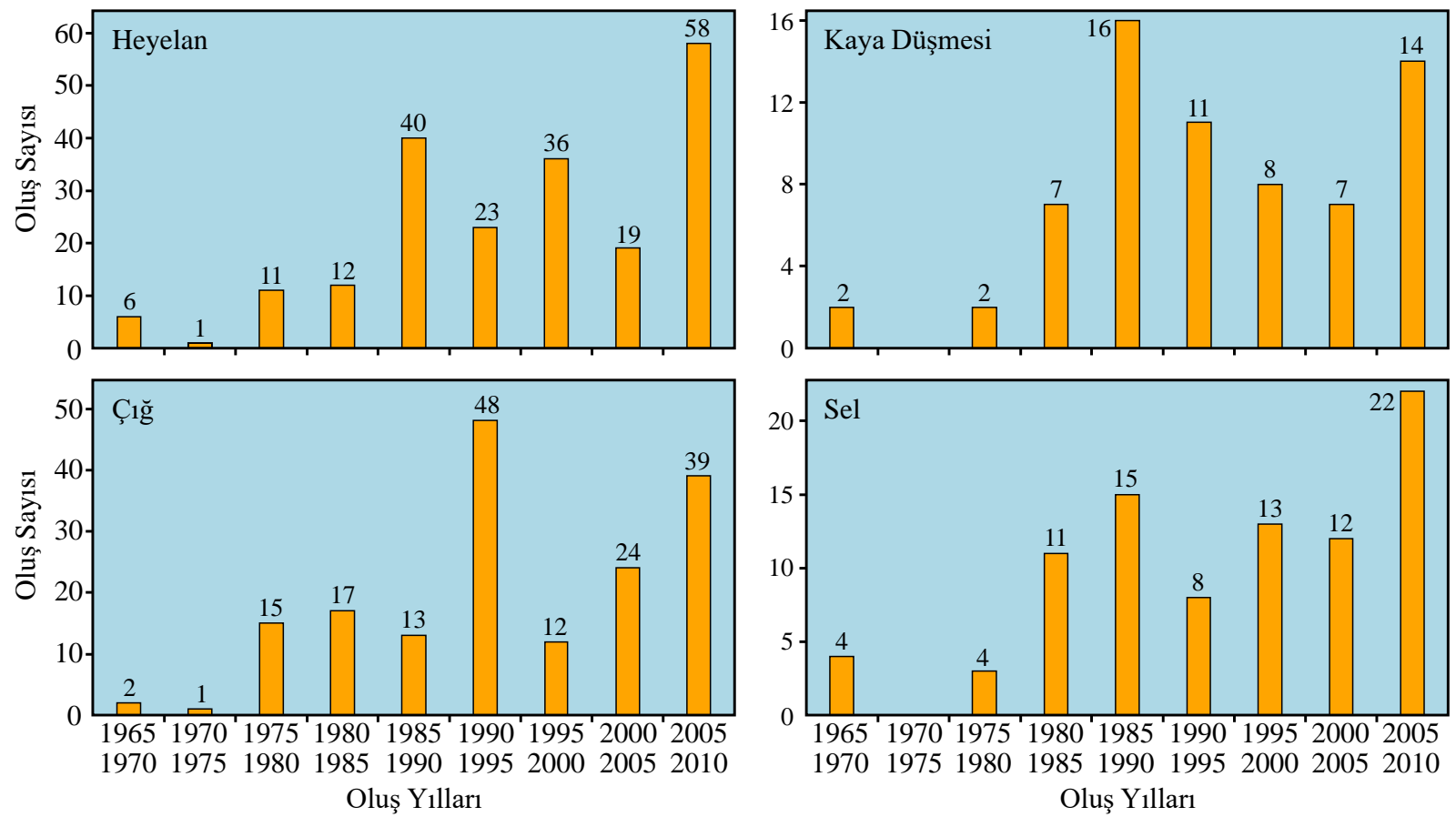

Şekil 5: Bitlis ilinde 1965-2010 yılları arasında gerçekleşmiş heyelan, çığ, kaya düşmesi ve sel olaylarının sayısının yıllara göre dağııımı

Tablo 8: Bitlis ili için heyelan, çığ, kaya düşmesi ve sel risk analizi sonuçları

\begin{tabular}{ccccccc}
\hline Afet Türü & Lokasyon & $\mathrm{O}$ & $\mathrm{F}$ & $\mathrm{D}$ & $\mathrm{R}$ & Sonuç \\
\hline \multirow{5}{*}{ Heyelan } & Adilcevaz & 1 & 0.5 & 15 & 7.5 & Kabul edilebilir risk \\
& Ahlat & 3 & 1 & 15 & 45 & Kesin risk \\
& Güroymak & 3 & 1 & 15 & 45 & Kesin risk \\
& Hizan & 10 & 10 & 15 & 1500 & Çok yüksek risk \\
& Merkez & 10 & 2 & 15 & 300 & Yüksek risk \\
& Mutki & 10 & 10 & 15 & 1500 & Çok yüksek risk \\
& Tatvan & 3 & 1 & 15 & 45 & Kesin risk \\
\hline \multirow{5}{*}{ Çı̆̆ } & Adilcevaz & 0.2 & 0.5 & 1 & 0.1 & Kabul edilebilir risk \\
& Ahlat & - & - & - & - & - \\
& Güroymak & 0.5 & 0.5 & 15 & 3.75 & Kabul edilebilir risk \\
& Hizan & 3 & 6 & 15 & 270 & Yüksek risk \\
& Merkez & 6 & 6 & 100 & 3600 & Çok yüksek risk \\
& Mutki & 10 & 10 & 100 & 10000 & Çok yüksek risk \\
& Tatvan & 6 & 3 & 100 & 1800 & Çok yüksek risk \\
\hline \multirow{5}{*}{ Kaya } & Adilcevaz & 0.2 & 0.5 & 15 & 1.5 & Kabul edilebilir risk \\
& Ahlat & 0.2 & 0.5 & 1 & 0.1 & Kabul edilebilir risk \\
& Güroymak & - & - & - & - & - \\
& Hizan & 3 & 2 & 15 & 90 & Önemli risk \\
& Merkez & 3 & 1 & 15 & 45 & Kesin risk \\
& Mutki & 3 & 2 & 15 & 90 & Önemli risk \\
& Tatvan & 1 & 1 & 15 & 15 & Kabul edilebilir risk \\
\hline \multirow{6}{*}{ Sel } & 1 & 1 & 15 & 15 & Kabul edilebilir risk \\
& Adilcevaz & 1 & 1 & 1 & 3 & Kabul edilebilir risk \\
& Ahlat & 0.2 & 0.5 & - & 15 & Kesin risk \\
& Güroymak & 3 & 1 & 15 & 15 & Kesin risk \\
& Hizan & 3 & 0.5 & 15 & Kesin risk \\
& Merkez & 3 & 1 & 15 & Yüksek risk \\
& Mutki & 6 & 3 & 15 & 15 & Kabul edilebilir risk \\
\hline & Tatvan & 0.5 & 0.5 & 15 & 15 &
\end{tabular}




\section{Sonuçlar}

Türkiye genelinde doğal afet çeşitliliğinin en yoğun yaşandığı yerleşim yerlerinden biri olan Bitlis ilinde meydana gelmiş heyelan, kaya düşmesi, çı̆̆ ve sel gibi doğal afet türleri incelenmiştir. 1965-2010 yılları arasında meydana gelmiş doğal afet verileri kullanılarak Fine-Kinney yöntemi yeni bir ölçek yardımıyla uygulanmış ve risk analizleri yapılmıştır. Heyelan, kaya düş̧esi ve çığ olaylarının eğimli topoğrafyalara sahip olan, bol yağış alan ilçelerde günlük hayatı tehlike altına alabilecek seviyelerde gerçekleştiği görülmüştür. Bitlis ilinin Türkiye'de en fazla kar yağışı alan il olması ve topoğrafyanın oldukça sarp ve dik yamaçlardan oluşması nedeniyle, ülkemizde çı̆̆ düşmesi olayı en çok Bitlis ilinde meydana gelmektedir. Çığ tehlikesi görülen alanların yakınlarındaki yerleşim yerleri için konum değişikliği planlanmalıdır. Çığ gözlem istasyonları kurularak, çığ oluşan alanlarla ilgili konumlama ve envanter çalışmaları yapılmalıdır. Ulaşım sistemlerini etkileyecek çığ olaylarının olduğu bölgelerde bariyerler veya çığ tünelleri kullanılabilir. Hizan, Mutki ve Merkez ilçe kırsalında kaya düşmesi olaylarına rastlanmaktadır. Bitlis Merkez ilçede çok ciddi şekilde kaya düşmesi olayı yaşanmamasına rağmen nüfusun ve yerleşimin yoğun olduğu mahallelerde riskin yüksek olduğu unutulmamalıdır. Özellikle Bitlis genelinde yaygın şekilde görülen volkanik kayaçların varlığı ve bunlar içerisinde ayrışma potansiyeli oldukça yüksek olan ignimbiritler, bazalt sütunları gibi jeolojik oluşumlar, aşırı yağış gibi meteorolojik koşullar nedeniyle kolaylıkla düşey devrilme gösterebilmektedir. Bu tür alanların tespiti son derece kolay olup gözleme dayalı olarak dahi belirleme yapılabilmektedir. Bu tespitlerden sonra ilk aşama olarak düşme potansiyeli olan kayaların temizlenmesi gerçekleştirilebilir. Bunun yanı sıra risk oluşturan kaya bloklarının sağlam zemine sabitlenmesi için ankraj, zemin çivisi, tel ağ (çelik grid-çelik kompozit grid) ve yüksek enerji sönümleyici paneller uygulanması gibi farklı mühendislik önlemleri ile çözümler üretilebilir. Adilcevaz, Ahlat ve Tatvan gibi Van Gölü’ne kıyısı olan ilçelerde sel riski kabul edilebilir düzeydedir. Buna karşılık dağlık alanlardan oluşan ve aşırı yükseltilerin olduğu Bitlis Merkez, Hizan ve Güroymak ilçelerinde kesin risk ve Mutki'de ise yüksek risk söz konusudur. Özellikle çok kar yağışı alan bu alanlarda iklimsel özellikler bakımından mevsim geçişleri keskin olmaktadır. Bu nedenle özellikle nisan-mayıs aylarını kapsayan bahar dönemlerinde sel olaylarına fazlaca rastlanmaktadır. Taşkınların etkisini azaltmak adına, dere sslah çalışmaları yapılmalı, dere yataklarında yeterli miktarda bent ve gölet inşa edilmelidir. Bitlis ili heyelan olayı bakımından oldukça fazla sorun yaşayan şehirlerden biridir. Özellikle Hizan ve Mutki oldukça yüksek risk taşıyan yerleşim yerleridir. Bu alanların yanı sıra Bitlis Merkez ilçesinde de yüksek risk söz konusudur. Yalnızca Adilcevaz ilçesi kabul edilebilir risk düzeyindedir. Diğer afet türlerine oranla heyelanlı alanlarda önlem almak daha kolaydır. Heyelan riski olan bölgelerde dayanma yapıları inşa edilmelidir. Yamaç dengesini bozacak uygulamalardan kaçınılmalıdır. Yamaçların teraslanması, drenaj ve ağaçlandırma çalışmaları heyelan riskini azaltabilecek önlemler arasındadır. Diğer yandan afetler açısından ele alınabilecek önlemlerin bir diğer boyutu etkilenecek insan sayısını azaltmak olabilir. Bu amaçla heyelan, sel, çığ ile kaya düşmelerinin kentsel ve kırsal yerleşimler üzerindeki etkilerini azaltmak için, öncelikle yersel tehlike olasılıklarını göz önünde tutarak, risk oluşturacak bölgelerde yapılaşmayı kontrol altına almak, mevcut riskleri ise azaltmak gereklidir. Kayıpların en aza indirgenmesi için doğal afet bölgeleri belirlenerek yapılaşma yasăg 1 uygulanmalıdır. Doğal afetlere duyarlılık haritaları elde edilerek risk öncelikleri dikkate alınarak gerekli müdahaleler yapılmalidır.

\section{Teşekkür}

Çalışma, Rezzan Ekinci tarafından Bitlis Eren Üniversitesi Fen Bilimleri Enstitüsü, Acil Durum ve Afet Yönetimi yüksek lisans programında hazırlanmış olan tez çalışmasının bir kısmını kapsamaktadır. Verilerin sağlanmasında destek ve yardımlarını esirgemeyen Bitlis İl Afet ve Acil Durum Müdürlüğü’ne teşekkür ederiz. Ayrıca makalenin son haline gelmesinde yapıcı eleştirileri ile oldukça katkı sağlayan hakemlere teşekkür ederiz.

\section{Kaynaklar}

Aydar E., Gourgaud A., Ulusoy I., Digonnet F., Labazuy P., Sen E., Bayhan H., Kurttas T., Tolluoglu A.U., (2003), Morphological analysis of active Mount Nemrut stratovolcano, eastern Turkey: evidences and possible impact areas of future eruption, Journal of Volcanology and Geothermal Research, 123(3-4), 301-312.

Birgören B., (2017), Fine Kinney risk analizi yönteminde risk faktörlerinin hesaplama zorlukları ve çözüm önerileri, Uluslararas1 Mühendislik Araştırma ve Geliştirme Dergisi, 9(1), 19-25.

Boray A., (1973), The structure and metamorphism of the Bitlis area, southeast Turkey. Doktora Tezi, Londra Üniversitesi, Londra.

Boray A., (1975), Bitlis dolayının yapısı ve metamorfizması, Türkiye Jeoloji Kurultayı Bülteni, 18, 81-84.

Bulut Ö., Büyüksaraç A., Işık E., Aydın C., Ekinci Y.L., (2018), Bitlis il merkezinde gözlemlenen kaya düşmeleri, 4. Uluslararası Mesleki ve Teknik Bilimler Kongresi, Erzurum, ss.1094-1102.

Çubukçu H.E., Ulusoy İ., Ersoy O., Aydar E., Şen E., Gourgaud A., Guillou H., (2012), Mt Nemrut Volcano (Eastern Turkey): temporal petrological evolution, Journal of Volcanology and Geothermal Research, 209(210), 33-60.

Degens E.T., Wong H.K., Kempe S., (1984), A geological study of Lake Van, Eastern Turkey, Geologische Rundschau, 73(2), 701734.

Deniz O., Doğu A.F., Yıldız M.Z., Saraçoğlu H., Kerimoğlu G., (2006), Süphan Dağı'nın buzul morfolojisi ve turizm açısından değerlendirilmesi, I. Uluslararası Coğrafya Çalışmaları Sempozyumu, Van, ss.113-126. 
Ekinci R., Büyüksaraç A., Ekinci Y.L., (2018), Seismicity and Seismic Hazard Parameters of Bitlis Province and its Surrounding. International Conference on Science, Technology, Engineering, Mathematics and Educational Science, Muş, ss.228229.

Elmastaş N., Özcanlı M., (2011), Bitlis ilinde çı̆̆ afet alanlarının tespiti ve çı̆̆ risk analizi, VI. Ulusal Coğrafya Sempozyumu, Ankara, ss.303-314.

Fine W.T., (1971), Mathematical evaluation for controlling hazards, Journal of Safety Research, 3(4), 157-166.

Gökçe O., (2008), Afet olay ve zararlarının il ve ilçelere göre dağılımı, T.C. Bayındırlık ve İskan Bakanlığı, Afet İşleri Genel Müdürlüğü, Afet Etüt ve Hasar Tespit Dairesi, İmar Planına Esas Jeolojik Jeoteknik Etüt ve Projeler Şubesi Projeler Şefliği, Ankara (https://www.afad.gov.tr/upload/Node/3503/xfiles/93-2014060215017-afetler_il_ilce_final_27102008_3.pdf).

Gökçe O., Özden Ş., Demir A., (2008), Türkiye’de afetlerin mekânsal ve istatistiksel dağllımı afet bilgileri envanteri, T.C. Bayındırlık ve İskan Bakanlığı, Afet İşleri Genel Müdürlüğü, Afet Etüt ve Hasar Tespit Daire Başkanlığı Raporu, Ankara.

Göncüoğlu CM., Turhan N., (1983), Bitlis masifinde yeni yaş bulguları, MTA Dergisi, 95(96), 44-48.

Güler Ç., Çobanoğlu Z., (1994), Afetler, TC Sağlık Bakanlığı, Temel Sağlık Hizmetleri Genel Müdürlüğü Yayınları, Çevre Sağlığı Temel Kaynak Dizisi, 33.

Gür H., Sönmez FY., Ay M., (2012), Bitlis İli Çevre Durum Raporu, T.C. Bitlis Valiliği Çevre ve Şehircilik İl Müdürlügü̈.

Horasan G., Boztepe-Güney A., (2007), Observation and analysis of low-frequency crustal earthquakes in Lake Van and its vicinity, eastern Turkey, Journal of Seismology, 11(1), 1-13.

Hosny G., Elghayish M., Noweir K., (2017), Health risk assessment for benzene-exposure in oil refineries, International Journal of Environmental Science and Toxicology Research, 5(1), 23-30.

Hoyois P., Below R., Scheuren J.M., Guha-Sapir D., (2007), Annual disaster statistical review: numbers and trends, Centre for Research on the Epidemiology of Disasters (CRED), School of Public Health, Catholic University of Louvain, Brussels, Belgium.

Hall R., (1976), Ophiolite emplacement and the evolution of the Taurus suture zone, Southeastern Turkey, Geological Society of American Bulletin, 87(7), 1078-1088.

Işık E., Aydın M.C., Bakış A., Özlük M.H., (2012), Bitlis ve civarındaki faylar ve bölgenin depremselliği, Bitlis Eren Üniversitesi Fen Bilimleri Dergisi, 1(2), 153-169.

Işık E., (2013), Bitlis ilinin depremselliği, Erciyes Üniversitesi Fen Bilimleri Enstitüsü Dergisi, 29(3), ss.267-273.

Karakhanian A., Djrbashian R., Trifonov V., Phillip V., Arakelian S., Avagian A., (2002), Holocene-historical volcanism and active faults as natural risk factors for Armenia and adjacent countries, Journal of Volcanology and Geothermal Research, 113(1-2), 319-344.

Karaoğlu Ö., Özdemir Y., Tolluoğlu A.Ü., Karabıyıkoğlu M., Köse O., Froger J.L., (2005), Stratigraphy of the volcanic products around Nemrut Caldera: implications for reconstruction of the caldera formation, Turkish Journal of Earth Sciences, 14(2), 123143.

Kinney G.F., Wiruth A.D., (1976), Practical risk analysis for safety management (No. NWC-TP-5865), Naval Weapons Center China Lake CA.

McKenzie D.P., (1970), Platetectonics of the Mediter ranean region, Nature, 226(5242), 239-243.

Mason R., (1975), Bitlis Masifinin Tektonik Durumu, Cumhuriyetin 50. Y1l1 Yerbilimleri Kongresi, Ankara, ss.31-41.

MTA, Maden Etüt ve Arama Dairesi Başkanlığı, (2010), Bitlis İli Maden ve Enerji Kaynakları Raporu, Maden Tetkik ve Arama Genel Müdürlüğü, Ankara.

Okumuş D., Barlas B., (2015), Gemi inşaatı sektöründe $5 \times 5$ analiz matrisi ve Fine-Kinney yöntemlerinin uygulamalı bir karşıllaştırılması, Gemi ve Deniz Teknolojisi Dergisi, 22(204-205), 95-106.

Oturakçı M., Dağsuyu C., Kokangül A., (2015), A new approach to Fine Kinney method and an implementation study, Alphanumeric Journal, 3(2), 83-92.

Özçelik A., (2013), İş Sağllğg ve Güvenliğinde Fine-Kinney Yöntemiyle Risk Yönetimi: Mermer İşletmesi Örneği, Yüksek Lisans Tezi, Eskişehir Osmangazi Üniversitesi Fen Bilimleri Enstitüsü, Eskişehir.

Özdemir Y., Akkaya İ., Oyan V., Kelfoun K., (2017), A debris avalanche at Süphan stratovolcano (Turkey) and implications for hazard evaluation, Bulletin of Volcanology, 78(9), 1-13.

Özkul B., Karaman E., (2007), Doğal Afetler İçin Risk Yönetimi, TMMOB Afet Sempozyumu, Ankara, ss.251-260.

Özşahin E., (2013). Türkiye'de Yaşanmış (1970-2012) Doğal Afetler Üzerine bir Değerlendirme, 2. Türkiye Deprem Mühendisliği ve Sismoloji Konferans1, Hatay, ss.1-8.

Özşahin E., Kaymaz Ç.K., (2014), Avalanche susceptibility and risk analysis of eastern Anatolian Region using GIS, Procedia - Social and Behavioral Sciences, 120(2014), 663-672.

Öztürk B., Balkıs N., Güven K.C., Aksu A., Görgün M., Ünlü S., Hanilci N., (2005), Investigations on the sediment of Lake Van, II. heavymetals, sulfur, hydrogensulfide and thiosulfuric acid S-(2-amino ethyl ester) contents, Journal of Black Sea/Mediterranean Environment, 11(1), 125-138.

Şengün M., (1993), Bitlis masifinin metamorfizması ve örtü çekirdek ilişkisi, MTA Dergisi, 115, ss.1-13.

Toker M., Krastel S., Demirel-Schlueter F., Demirbağ E., İmren C., (2007), Volcano-Seismicity of Lake Van (Eastern Turkey), A Comparative Analysis of Seismic Reflection and Three Component Velocity Seismogram Data and New Insights into Volcanic Lake Seismicity. International Earthquake Symposium, Kocaeli, ss.103-109.

Uluğ A., (2009), Nasıl bir afet yönetimi, TMMOB İzmir Kent Sempozyumu, İzmir, ss.1-18.

Ulusoy İ., Labazuy P., Aydar E., Ersoy O., Çubukçu E., (2008), Structure of the Nemrut caldera (Eastern Anatolia, Turkey) and associated hydrothermal fluid circulation, Journal of Volcanology and Geothermal Research, 174(4), 269-283.

Ulusoy İ., Labazuy P., Aydar E., (2012), STcorr: an IDL code for image based normalization of lapse rate and illumination effects on nighttime TIR imagery, Computers and Geosciences, 43(2012), 63-72.

Yılmaz Y., Güner Y., Şaroğlu F., (1998), Geology of the Quaternary volcanic centers of the East Anatolia, Journal of Volcanology and Geothermal Research, 85(1-4), 173-210. 